\title{
Af Slogs herreds nationale historie indtil 1864
}

\section{Af Hans Vald. Gregersen.}

Alle de kort, der i tidens løb er fremstillet for at vise styrkeforholdet mellem danske og tysksindede i Nordslesvig, aftegner med ret stor skarphed et blandet område, der efter formen går under navnet „den skceve firkant“. Det drejer sig om et område, der mod syd følger landegrænsen fra Højer til henimod Gråsten og imod nord når på højde med Nørre Løgum og Øster Løgum sogne. Købstæderne Tønder og Åbenrå samt Løgumkloster flække ligger inden for denne firkant, som det under indtryk af det hitleristiske Tysklands ekspansive tilbøjeligheder $i$ trediverne også blev almindeligt at kalde "den truede firkant".

Den sydligste, centrale del af dette område udgøres af Slogs herred, omfattende de seks sogne Hostrup, Højst, Rabsted, Bylderup, Burkal og Tinglev, hvortil indtil 1850 endnu kom den vestlige del af Bjolderup og Uge sogne. Ved folkeafstemningen i 1920 faldt der i det nuværende Slogs herred 2176 danske og 1932 tyske stemmer, altså henholdsvis 53 og 47 pct., men i årene før verdenskrigen opviste herredet som helhed tysk flertal. Det var derfor ikke uden grund, at den tyske regerings daværende sagkyndige i spørgsmål vedrørende den dansk-tyske grænse, Johannes Tiedje, foreslog herredets nordgrænse som fremtidigt grænseskel, den såkaldte Tiedje-linje. Sammenlagt med det store tyske flertal i Tønder og Højer kunne der faktisk påvises et knebent tysk flertal på 6735 stemmer mod 5658 danske stemmer i de 76 distrikter, som 
"Tiedje-bæltet" omfattede. Grænseområdet er derfor hjemmetyskhedens højborg.

Man har adskillige gange søgt at give en historisk forklaring på, hvorfor hjemmetyskerne sindelagsmæssigt har udskilt sig fra Nordslesvigs øvrige befolkning. Det har således både fra dansk og tysk side længe været en almindelig mening, at hjemmetyskheden skulle have en af sine rødder $i$ den gottorpske statspatriotisme, idet den skæve firkant tilhører det gamle gottorpske område. Der findes ganske vist også eksempler nok på, at befolkningen $\mathrm{i}$ de gottorpske egne omkring år 1700 nærede den storste sympati for fyrstehuset i Slesvig. Den hjemmetyske historiker Ludwig Andresen har $\mathbf{i}$ en afhandling om hjemmetyskheden i den skæve firkant fremdraget adskillige interessante eksempler herpå ${ }^{11}$, og de lader sig endda nemt supplere'). Men hverken Ludwig Andresen eller andre har formået at give et fuldgyldigt bevis for, at denne gottorpske statspatriotisme skulle have holdt sig uafbrudt helt op til den nationale vækkelse i $1830^{\prime}$ og 40'erne. Ved mageskiftetraktatens undertegnelse i 1773 gav huset Gottorp tilmed definitivt afkald på alle dets rettigheder i hertugdommerne, og omkring det påfølgende århundredskifte prægedes Slesvig derfor lige så vel som enhver anden del af monarkiet af undersåtlig loyalitetsfølelse for den enevældige konge i København.

Troels Fink har derfor hævdet'), at der ikke kan tillægges gottorperstyret den betydning som forudsætning fcr hjemmetyskheden, som det har været almindeligt. Større

3) Ludwig Andresen: Geschichtliche Voraussetzungen, Entwicklung und Durchbruch des Nationalbewusstseins des Heimdeutschtums im - Schiefen Viereck in Nordschleswig (Deutsche Hefte für Volksforschung III, 208-220; IV, 41-58 (1933-34); jf. Der Schleswig-Holsteiner 1934, 233-240, 267-272, 297-301 og 331-335.

2) Hejselbjerg Paulsen: Sønderjydske Slægter I. Øster Løgum (1941), s. $83 \mathrm{f}$;; S $\phi$ nderjydske årb $\varnothing$ ger 1949 , s. $56 \mathrm{ff}$; Bjolderup sogns historie (1951), s. $83 \mathrm{ff}$.

3) Troels Fink: Gottorperstyret som forudsætning for hjemmetyskheden i Nordslesvig (Fortid og Nutid XV, 107-119). 
betydning vil han derimod tillægge den påvirkning, der er udgået fra de nordslesvigske præstegårde, hvor der til trods for det danske kirkesprog ofte levedes et tysk kulturliv.

Man kan dog vist anse det for givet, at det ikke lader sig gøre at sige noget generelt om den historiske baggrund for hjemmetyskheden i Nordslesvig som helhed. Dens sen€re styrke $i$ enkelte egne lader sig endog undertiden tilskrive rene tilfældigheder. ${ }^{4}$ ) Vi skal derfor $\mathbf{i}$ det følgende prøve at undersage forholdene i Slogs herred, der som et af hjemmetyskeriets kerneområder netop må siges at være af særlig interesse for en bedømmelse af hjemmetyskhedens historie.

En af dens vigtigste forudsætninger på denne egn vil Ludwig Andresen finde i det gamle fæstevæsen, der har været mere udbredt i Slogs herred end andetsteds. Befolkningen skulle derigennem være blevet knyttet særligt nær til ovrigheden. Det er dog et spørgsmål, om man ikke bør tillægge grev Adolf VIII s privilegiebreve til en række frigårde i strøget mellem Flensborg, Åbenrå og Tonder nok så stor betydning

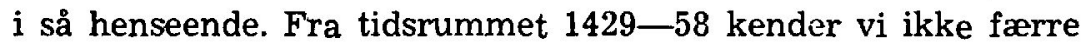
end 40 frihedsbreve ${ }^{3}$ ). For Slogs herreds vedkommende kan vi således optegne Nolde (1437 og 1450), Frestrup (1445), Bredevad (1450 : 2 gårde), Rebbøl (1450 : 2 gårde), Bylderup og Hajstrup (1453?), samt Heds mark (1455). Uden tvivl har grev Adolf med denne privilegietildeling bevidst sogt at knytte egnens storbønder til sig efter de mange omvæltninger, som hans kampe med Erik af Pommern havde forårsaget,og den har været et led i hans bestræbelser for at knytte Sønderjylland sammen med Holsten. Man kan derfor med alt forbehold føle sig fristet til at opfatte disse danskættede storbønder, der lod sig udmærke af den schaumburgske greve, som vore første hjemmetyskere.

Ganske vist skulle der hengå adskillige århundreder, inden der blev tale om nationale forhold i moderne forstand, men

4) Sønderjydske årb фger 1951, s. $161 \mathrm{ff}$.

i) G. Hille: Registrum Christians I (1875). 
ciet har dog alligevel haft sin betydning, at tyskheden - om ikke folkeligt, så dog socialt og efterhånden også $i$ det udvortes kulturelt - fik tag i adskillige af de forende bondeslægter i Slogs herred. Denne proces indlededes netop i en tid, hvor tyskheden okonomisk var i en rivende udvikling, hvilket medførte en delvis folkelig erobring af adskillige sønderjydske byer $\left.{ }^{0}\right)$.

De mange plattysk skrevne tingsvidner, der dukker op efter 1400, må tages som udtryk for det samme. Ganske vist fortæller de intet om bondefolkets hjemmesprog, men de vidner om tyskhedens kulturelle overlegenhed, og der forekommer aldrig klager over, at man ikke forstod det plattyske mál. For Slogs herreds vedkommende findes der $\mathrm{j}$ tiden 1470155017 danske tingsvidner jævnsides med 34 plattyske. En ciobbeltudfærdigelse fra 1491 på både dansk og plattysk kunne dog måske tolkes derhen, at det plattyske sprog ikke var lige let tilgængelig for alle. Måske har den slags dobbeltudfærdigelser endda slet ikke hørt til undtagelserne ${ }^{7}$ ).

Den lutherske reformation har utvivlsomt fremmet denne proces stærkt, og alligevel har den ikke des mindre i det lange 1eb sikret Nordslesvig fra folkelig undergang, idet det betydningsfuldeste kulturelle skel, der $\mathrm{i}$ de sidste fem århundreder er blevet trukket mellem dansk og tysk i Sønderjylland, faktisk blev grænsen imellem dansk og tysk kirkesprog, der i 1920 i hovedtrækkene blev normgivende for den nuværende dansktyske grænse.") Efterhånden som et folkeligt skolevæsen kom i gang, blev denne linje også grænse imellem dansk og tysk skolegang.

I tiden fra 1581 til 1721 var Slogs herred en del af det gottorpsks hertugdømme. Selv om man vel nok - som foran på-

6) S. årb. 1950, 192- 193.

7) Peter Skautrup: Det danske Sprogs Historie II. 31-34 (kort s. $164 \mathrm{og}$ s. 300 ),

8) Interessante enkelth. vedr. kirkesprogsgrænsen vil man finde $i$ Schriften d. Vereins f. schl.-holst. Kirchengeschichte, 2. rk., 10. bd., 1. hefte s. $79 \mathrm{ff}$. (Th. O. Achelis). 
peget-inogen grad harovervurderet gottorperstyrets betydning som fortyskningsfaktor, siger det os dog, at Slogs herred igennem dette tidsrum stod $\mathrm{i}$ den allernærmeste åndelige og timelige vekselvirkning med egnene sydpå, et forhold, der stort set også varede ved $\mathrm{i}$ årene efter inkorporationen. På det åndelige område kan her fremhæves bevægelser som pietismen og herrnhutismen, og økonomisk har studehandelen i høj grad formidlet de sydgående forbindelser. Med hensyn til de to religiøse retninger må det dog fremhæves, at de i første række henvendte sig til lægfolket, og de måtte derfor som følge af det danske kirke- og talesprog i Slogs herred i overvejende grad iklædes dansk dragt.

Alt i alt var åndelig virksomhed ud over det rent religiøse i ældre tid ganske fremmed for Slogs herreds landbefolkning. Som følge deraf var endnu ved indgangen til det 19. århundrede kendskabet både til det danske og tyske skriftsprog kun begrænset. Og da en materialistisk livsopfattelse tilmed nu satte sig til rette rundt om i præstegårdene i rationalistisk klædebånd, bedredes dette ingenlunde. I strøget mellem Åbenrå og Tønder fandtes ingen betydelige præster blandt datidens rationalister. Studeopdræt og handel med stude og heste krævede ikke større vindskibelighed, og præsterne var derfor ofte langt bedre som l'hombrespillere og tobakssmøgere end som kristendomsforkyndere ${ }^{\theta}$ ).

Først ind $\mathrm{i}$ det nye århundrede begyndte et nyt liv at røre sig i præstegårdene. Det var efterdønningerne efter Claus Harms' forkyndelse, der for hertugdømmerne fik en lignende virkning — $\mathrm{cm}$ end næppe så dybtgående - som Grundtvig forårsagede i kongeriget.

9) Generalsuperintendent Adler, der var hertugdømmernes førende rationalist, fortæller sảledes i sin \$Predigerprotokol om nogle af herredets præster følgende:

Beyer (Burkal 1830-37) driver kvæghandel,

Bjørnsen (Højst 1825-49) i fare for at blive fordrukken,

Eichel (Hostrup 1767-1813) under al kritik.

Krongaard, Bylderup, 1821-32) lever dărligt med sin kone, har ingen agtelse $i$ menigheden.

(Efter S. ârb. 1936, s. 204). 
Men den nye tid bragte også politikken ind i menigmands tilværelse. Til den første slesvigske stænderforsamling i 1836 lod man sig i Slogs herred repræsentere af gårdmand Thies Hansen Steenholdt fra Rabsted og storbonden Peter Todsen på Mejerholm ved Tonder med gårdmand Martin Adolph i Nolde som suppleant. Det er dog endnu for tidligt ved dette valg at tale om en national tilkendegivelse. Det viser således bedst de to stænderdeputeredes stilling til Nis Lorenzen Lilholts andragende om at måtte få det danske sprog indført som rets- og forvaltningssprog i de egne, hvor det i forvejen var kirke- og skolesprog. Steenholdt udtalte under forhandlingerne herom i 1838, at han i taknemmelighed ville påskønne det, når det danske sprog blev indført ved retten, selv om det ikke syntes ham nødvendigt, idet han aldrig havde hørt klager over, at der skulle være forekommet noget urigtigt på grund af brugen af det tyske sprog. Han gjorde sig derfor samtidig til talsmand for øget undervisning i det tyske sprog i Nordslesvig; "dette ville finde stor interesse og gøre nytte. " ${ }^{10}$ )

Men hermed blev faktisk den gnist sluppet løs, der efterhånden skulle fả den nationale brand til at blusse op $i$ folkets hjerter. Da det kongelige reskript om brugen af dansk øvrighedssprog udsendtes den 14. maj 1840, var situationen en ganske anden: Steenholdt havde i mellemtiden sluttet sig til hertugen af Augustenborg - under indflydelse af tingskriver Hans Adolf Jacobsen i Slogs herred, mener P. Lauridsen. I hvert fald rejste de to mænd rundt til herredets samtlige sognefogeder og befuldmægtige (ialt 28) og fik disses underskrift på et bønskrift, der anmodede kongen om, at reskriptet ikke måtte blive gennemført for Slogs herreds vedkommende, thi deres sprog var „kein ächtes Dänisch“!

I den slesvigske stænderforsamling i 1840 faldt det derfor naturligt i Steenholdts lod at forklare grunden til sit omsving fra 1838. Han tog tråden op fra sin sidste stændertale ved at

10) Slesvigske Stændertidende 1838, s. 596. 
hævde, at der ikke kendtes noget tilfælde, hvor én havde lidt uret som følge af de tidligere tilstande. „Beboerne i de nordlige landdistrikter ville lige så lidt kunne forstå det "højdanske“ forretnings- og retssprog som det højtyske!" Der ville faktisk med reskriptet ske en stor ulykke, „fordi vi elsker det tyske sprog og det, som vi læser på tysk, og ikke vil undvære kendskabet til det eller brugen af det og heller ikke kan undvære det ved vort daglige samkvem med den sydlige del af hertugdømmet. Enhver fader ønsker, at hans børn lærer tysk så godt, som det er muligt"." )

Steenholdt kom dog aldrig selv trods alle mulige anstrengelser til at beherske det tyske sprog. Hvad der findes af skriftlige efterladenskaber fra hans hånd, viser det med al tydelighed. ${ }^{12}$ ) Og hans lille autografsamling var ingenlunde ene om at repræsentere herredets offentlige mening.

En ung teolog fra Højst var trådt ind på scenen. Nis Hansen, "Bondesøn", som han yndede at kalde sig, var en hjemstavnens mand, der ville gøre "sit elskede Slesvig til den lykkeligste plet på jorden", og det, der savnedes, var frem for alt oplysning. Det lykkedes ham i 1839 at få en kreds af københavnske sønderjyder samlet omkring dannelsen af "Selskabet for dansk Læsnings Udbredelse i Slesvig“. I lobet af de følgende fire år var denne forening $i$ stand til at forsyne omtrent 60 bogsamlinger med ikke færre end 20,000 bind. ${ }^{13}$ ) I Slogs herred fik Højst, Rabsted og Rørkær bogsamlinger. I sidstnævnte by, hvor en lærer og en skrædder var de lokale foregangsmænd, blev dette af skelsættende betydning. ${ }^{14}$ )

Men at prisen for oplysningsarbejdet til gavn for hans kære hjemstavn skulle være den, at befolkningen splittedes politisk, var ham længe ufatteligt. Endnu så sent som i 1840 søgte han i

11) Slesv. Stændertidende 1840, s, 38.

12) En prøve er givet S. mdsskr. 1948, s. 218--219.

13) P. Lauridsen: Da. Sønderjylland vaagnede III, s. 13-19. 108; VI, s. 35 .

14) S. mdsskr. 8 årg., s. 27 f.; 1948, s. 146 ff.; 1949, s. 64. 
lighed med Orla Lehmann, der brevvekslede med Peter Hiort Lorenzen, at vinde sine landsmænd Steenholdt og Todsen for sine tanker om den fælles hjemstavns fremtid. „I Danmark er der vågnet en ånd, som man trøstigt kan slutte sig til. Slesvig har intetsomhelst at frygte af Danmark, men meget at håbe. Hvad kan vi derimod vente af Holsten og Tyskland? I Holsten er aristokratiet alt for mægtigt." De to hjemmetyskere lod sig imidlertid ikke overtale til at gå $\mathrm{i}$ Peter Hiort Lorenzens fodspor, men offentliggjorde brevene med svar i Tondernsche Intelligenzblatt den 5 , august $18400^{15}$ ) Processen var fuldbyrdet: også Slogs herreds befolkning var delt i to nationale lejre.

Dog var de brede lag sig endnu langt fra en sådan udvikling bevidst. Bortset fra rivningerne under stænderdebatterne og lidt avisskriverier i ny og næ mærkede man faktisk i det daglige uhyre lidt til politik. Landalmuen — som man efter tidens skik plejede at udtrykke sig - var stadig præget af en dybt indgroet bondekonservatisme. En mand som herredsfoged Eerend Feddersen var et mønster på en embedsmand fra denne tid. Under kriseårene i 1820'erne havde han været herredet en god mand. „Endog til tab for egen interesse havde han ved skånende behandling holdt mangen familie ved dens besiddelser og husly“. Med en henvisning til Ordsprogenes 19. kapitel 17. vers sluttes minderunen over ham i Dannevirke den 10. april 1841. I anledning af hans bortgang kunne faktisk noget lignende siges som ved Frederik VI's død i 1839: med ham gik den gamle tid i graven.

Det var fra nu af Thies Steenholdt, der skulle præge herredet; han tiltrådte for øvrigt netop i det selvsamme år som sognefoged for Rabsted sogn (21. april 1841). Det hed i anledning af hans udnævnelse, at Rabsted kun besad få personer, som-var kvalificerede til en sådan stilling. Thies Steenholdt „nød agtelse og anseelse $i$ hele sognet, ligesom han besad kraft og energi til at bringe sognefogedforretningerne $i$ orden". Da han tilmed var

15) Efter L. Andresen: Geschichtl. Voraussetzungen etc. 
bosat i sognets kirkeby, fandt amtet det naturligt netop at udpege ham. ${ }^{16}$ ) Derimod så det sig overhovedet ikke foranlediget til at omtale hans virke som stænderdeputeret! Hans udnævnelse til sognefoged har kun kunnet bibringe menigmand den cpfattelse, at myndighederne bifaldt hans virke i stænderforsamlingen.

„Kraft og energi“" har altså i særlig grad udmærket denne mand, der politisk helt og holdent lod sig lede af hertugen af Augustenborg og derfor pả ingen måde kom til at tilhøre den moderate fløj inden for slesvigholstenismen. Hans ildhu endte med også at skaffe ham modstandere i sit eget hjemsogn. David Bargum i Havsted, med hvem han i 1841 havde konkurreret om sognefogedværdigheden, repræsenterede således det mere mådeholdne element inden for hjemmetyskheden. Spændingen imellem de to fløje blev akut under treårskrigen.

Nytårsaften 1848 indlod Thies Hansen sig på en jagt efter en ung mand, der var flygtet nordpå for at undgå indkaldelse til den slesvigholstenske oprørsarmé, men som i anledning af helligdagene havde dristet sig til at vende hjem til sine forældre i Havsted. Nogle dårlige elementer foranstaltede da med sognefogedens billigelse optøjer $i$ den ellers så stille landsby, mens gårdmand David Bargum trods sit hjemmetyske sindelag forholdt sig passiv. ${ }^{17}$ ) Thies Steenholdt har åbenbart herved mistet den goodwill, han endnu kunne siges at være i besiddelse af, idet han nogle dage senere, den 3 . januar 1849, anmodede om at måtte blive fritaget for hvervet som sognefoged i Rabsted sogn.

Rabsted har jo ellers i tidens løb gjort sig så kendt for sine hjemmetyske sympatier, at det endog er blevet kaldt „Klein Berlin". Hvad kan grunden have været til denne besynderlighed, spørger man uvilkårligt. Blader man i de gamle visitatsprotokoller fra tiåret før treårskrigen, findes sognet gennem-

16) LA. Tdr. amtsarkiv. Sager ang. udnævnelser af sognefogeder $1835-49$.

17) S. mdsskr. 1948 , s. $218-220$. 
gående rosende omtalt, hvad almenoplysningen angår. ${ }^{18}$ ) Lærerne roses således for deres flid og iver i skolegerningen. Dansk læsning blev drevet til fuldkommenhed, men også i det tyske sprog havde i hvert fald de klogtigste gode kundskaber. I løbet af 1840 'erne fremmedes tyskundervisningen i sognets skoler. Det siges udtrykkeligt i 1839, at det især var pastor Bargums fortjeneste, at sognets skolevæsen var i så god en stand. Han virkede som sognets præst fra 1801 til 1847 og har således $\mathrm{i}$ over en menneskealder formået at sætte sit præg på sognet.

I 1842 karakteriseredes situationen på følgende måde: i Havsted, hvor der forst i 1838 var gjort en ringe begyndelse med undervisning i tysk, prægedes skolen af dansk læsning, i Foverup af hovedregning, i Korup af geografi og fædrelandshistorie, men i Rabsted af det tyske sprog. I 1844 hed det, at der ydedes mest i tysk i Rabsted og Havsted, hvor nogle elever også med færdighed kunne oversætte fra dansk til tysk. På den tid læstes der tysk i overste klasse i alle sognets skoler; i Foverup kunne børnene imidlertid mindst. Det er fristende at sammenligne disse oplysninger med afstemningsresultatet i 1920. Rabsted var da overvejende tysk, i Havsted stod det omtrent lige, mens Foverup udviste et klart dansk flertal.

For øvrigt var det ikke læreren, der påvirkede børnene $\mathrm{i}$ tysk retning. Lærer og degn Christian Christensen var tværtimod dansksindet og bestyrede således den foran omtalte bogsamling i sognet. ${ }^{19}$ ) Men hans indflydelse over for de velstående tysksindede bønder var kun ringe, og under oprøret blev han endog udsat for forfølgelser på grund af sin troskab imod konge og fædreland. Når det ikke kom til at gå ham værre, skyldtes det nok, at pastor Meyer holdt hånden over ham. Han fortjente efter præstens mening at hædres offentligt.. ${ }^{\text {) }}$ )

18) LA. Tdr. provstearkiv. Visitatsberetninger 1836-42, visitatsprotokoller $1838-45$.

19) RA. Regensburgs arkiv. Brev fra Joh. Kok $18527 / 11$.

2.) LA. Tdr. provstearkiv. Visitatsindberetninger $1852-53$. 
Treårskrigen gav ikke i Slogs herred anledning til nationale uoverensstemmelser i lighed med, hvad vi kender fra det tilgrænsende Åbenrå amt. ${ }^{21}$ ) Det var her storbønderne, der gav tonen an, og deres sympatier var overvejende hos slesvigholstenerne, idet man økonomisk så ganske og aldeles følte sig knyttet til Holsten og Hamburg.

Enkelte steder som i Rørkær og Bjolderup vestersogn sporédes der dog dansk liv. De særlige forhold i Rørkær er allerede berørt. Fra Bjolderup vestersogn har sognefoged Lorenz Jacobsen indberettet sine vanskeligheder med befolkningen. „Hvor jeg kommer, er Folket lidt vranten. Er du Provisorisk? Vi har ikke med Tyskerne at bestille. Den provisoriske Regjering [aner]kjender vi ikke; den har os ikke noget at befale osv. " ${ }^{\text {(22) }}$ Her gik stemningen altså tydeligt nok i dansk retning, men ellers karakteriseres herredet som helhed bedst ved, at de dansksindede forholdt sig rolige. De savnede foregangsmænd, der turde træde op imod den slesvigholstenske kaste af storbønder, præster og bestillingsmænd.

Men derimod bragte krigens ophør i høj grad forstyrrelser ind $i$ herredets liv, idet det nye danske styre indlod sig på en kraftig udrensning af alle illoyale embedsmænd. Muligvis gennemførtes denne udrensning noget hårdhændet uden til fulde at udvise den takt, som den slags foreteelser nu engang kræver af hensyn til den fremtidige udvikling i en befolkning, hvor modsatte anskuelser brydes. Faktisk opstod der også vanskeligheder med at finde frem til egnede personer, der kunne overtage de offentlige hverv, der som felge af udrensningen var blevet ledige. Dertil kom, at man for at få en bestalling måtte erlægge en temmelig høj sum (på den tid 54 mark courant for at blive sognefoged). Mange veg alene af den grund tilbage for at søge et offentligt hverv. Tønder amts nye amtmand, grev Arthur Reventlow, en loyal helstatsmand, der dog $i$ lobet af få år ragede ganske uklar med mange af de nye natio-

11) S. årb. 1951, s. $161-201$.

9.) S. mdsskr. 1950, s. $11-14$; Bjolderup sogns historie (1951), s. 227. 
nalliberale embedsmænd, der meget betegnende for deres opfattelse af forholdene efterhånden åbent beskyldte ham for at være en dulgt tysker, fik derfor gebyret afskaffet, hvilket var så meget mere påkrævet, som det faktisk var umuligt at finde loyale elementer inden for Slogs herreds velstillede bondestand. De underordnede embeders indflydelse på befolkningen anså greven imidlertid for at være „så umiddelbar og så stor, at det var af vigtighed at besætte dem med duelige, loyale og dansksindede mænd“. ${ }^{23}$ )

Men det kan som nævnt diskuteres, hvorvidt man gik frem med den fornødne takt. Sognefoged F. P. Höeck i Burkal følte sig i hvert fald forurettet. Han skrev derfor til amtshuset (1850 21/11): „Min kongelige Bestalling til Sognefoged for Buhrkall Sogn blev mig nylig affordret og jeg afsat fra mit Embede, uden at jeg kan tænke mig nogen lovlig Grund og Aarsag dertil. Saalænge jeg har forestaaet dette Embede, har jeg stedse været Kongen tro og huld, beviist den punctligste Lydighed mod mine høye Foresatte, og paa alle Maader sørget for den mig anbetroede Commünes Bedste. Jeg veed ikke at have forsømt eller forseet noget i nogen Henseende. Heller ikke troer jeg, at nogen har havt mindste Aarsag til at klage over mig. Det er virkelig haardt at finde sig i ...." Han slutter meget betegnende med at stille krav om at faa refunderet $25 \mathrm{rdl}$. courant, som han årligt i 6 år har betalt sin forgænger for at få embedet efter ham. Det materielle har altså også spillet ind i forargelsen.

Ansøgningen afvistes imidlertid, idet den nye herredsfoged, Eleaser Cohen, erklærede (på tysk), at supplikanten almindeligvis gjaldt for en meget tysk- eller slesvigholstensk-sindet mand og som sådan kun kunne være en imaginær hertug af Slesvigholsten tro og huld, men ikke Danmarks konge. Iøvrigt havde han ikke haft årsag til at beklage sig over manden. - Men

«) LA. Tdr. amtsarkiv. Journalsager 1850 G (hvorfra også de fø̣lgende oplysninger er hentet). 
hvor grundigt har bemeldte herredsfoged, der, som vi senere skal høre, ikke var uden brist, sat sig ind i denne sag?

Ofte har man sikkert kun haft alt for lost underbyggede rygter at holde sig til. Et eksempel fra Højst sogn synes at vise det. Herredsfoged Cohen nævner i slutningen af $1850 \mathrm{i}$ en omtale af sognefogederne, som han for den allerstorste dels vedkommende finder slesvigholstensk-sindede, at han hidtil kun har hørt om Peter Simonsen fra Holm, Højst sogn, at denne skulle have taget virksomt del i oprøret, idet han ved krigens udbrud havde tilskynder adskillige militærpligtige til at tage til oprørstropperne i Rendsborg. Iøvrigt ved herredsfogeden dog ikke andet at melde end, at samtlige sognefogeder har vist sig lydige og føjelige over for ham.

Tre uger senere synes han imidlertid at være blevet bedre informeret med hensyn til forholdene i Højst sogn. En henvendelse til pastor Hoxbroe havde nemlig givet til resultat, at der næppe lod sig finde et nyt emne til sognefogedværdigheden, og at beskyldningerne imod den hidtidige sognefoged faktisk kun hvilede på løse rygter. Præsten havde tværtimod af gode danske mænd fået forsikret, at sognefogeden var dansksindet! Det endte derfor med, at han beholdt sin bestilling.

Det skal dog siges til myndighedernes undskyldning, at det ofte var uhyre vanskeligt at udtale sig om enkeltpersoners nationale indstilling. Slogs herred var allerede dengang et område, hvor det „blakkede“ standpunkt stod i fuldt flor, mens de nationale tanker først meget sent formåede at slå rod. Med forbavsende sejghed har gammeldags ærbødighed over for den herskende øvrighed holdt sig på denne egn. Det er ikke udelukket, at denne holdning i første række skyldes det stærke islæt af pietisme og herrnhutisme, der i lighed med, hvad man senere har skudt missionsfolkene i skoene, adlød øvrigheden af hvad art den så end var - som indsat af Gud og derfor ikke lod sig forlede til at tage del i samtidens politiske og nationale foreteelser, som man anså for at høre „denne verden“ til. H. V. 
Clausen omtaler således en mand fra Havsted, der indtil 1848 var dansk, under opraret slesvigholstensk, i tiden mellem krigene igen dansk, efter 1864 påny sleswigholstensk for efter anneksionen at ende sine dage som preusser. ${ }^{24}$ )

Det er derfor ikke så underligt, at herredsfoged Cohen efterhånden så sig nødsaget til at anmode amtshuset om længere tid til vurdering af folks nationale sindelag, idet kun ganske få lod sig røjagtigt bestemme, mens han med hensyn til andre måtte nøjes med formoảninger, så meget mere som de dansksindede i Slogs herred var meget tilbageholdende med oplysninger om slesvigholstensksindede, hvad enten det så skyldtes frygt eller andre hensyn. Det, som det først og fremmest gjaldt om, var at få trofaste sognefogeder overalt $\mathrm{i}$ herredet.

Men det var lettere sagt end gjort. I Bylderup sogn var så] $\mathrm{E}$ des Chr. Hansen fra Nymølle blevet afsat, hvad han tog myndighederne meget ilde op. „Ingen Grund er mig beviist, hvorfor jeg har at entlediges," skrev han. Men det viste sig næsten ugørligt at finde en dansksindet afløser til ham med et antageligt mål hartkorn. Sluttelig faldt dog valget på Matthias Hansen Matthiessen i Bylderup, skønt han kun var 24 år gammel og endnu indkaldt til militærtjeneste. I 1867 anmodede han om sin afsked; som grund angav han, at han i sin tid nærmest var blevet presset til at overtage hvervet. En åben dansk bekendelse har han ikke turdet fremkomme med.

I Rabsted sogn kom bølgerne derimod til at gå højt. Som foran omtalt havde Thies Steenholdt nedlagt sit hverv som sognefoged ved begyndelsen af året 1849, og Nicolay Jürgensen Nicolaysen var da trådt i stedet. Efter oprørets sammenbrud afsattes han imidlertid af de danske myndigheder, skønt 51 Rabsted-boere $i$ et andragende til amtet bad om at måtte beholde ham under påskud af, at han havde erhvervet sig gode kundskaber om sognets særlige anliggender, som en anden vanskeligt ville tilegne sig. $\mathrm{Da}$ både Thies Steenholdts kone

21) S. årb. 1894, s. 93. 
(Thies var på den tid flygtet sydpå) og David Bargum har undertegnet andragendet, er det jo tydeligt nok sognets tysksindede, der har søgt at spænde ben for myndighedernes bestræbelser.

Let var det da heller ikke for den danske øvighed. Herredsfoged Cohen erklærede, at han ikke kendte nogen, der var egnet; det skortede ganske på loyale og dygtige landboere $i$ dette sogn. Valget faldt dog til sidst på Claus Nissen Jacobsen i Havsted, så den tyske aktion til fordel for den gamle sognefoged blev resultatløs. Til gengæld søgte de tysksindede så at skaffe den nye mand adskillige vanskeligheder. Det var ham således umuligt at sege oplysninger om sit nye hverv hos sine forgængere i embedet. Og allerede en måneds tid senere (13. dec. 1850) beklagede han sig over modstand fra sogneboernes side, idet de nægtede at yde ham de sædvanlige sportler. "Det er kuns ene og allene Parti[sk]hed, som her driver sit Spil,“ hedder det i hans klage til amtshuset. ${ }^{25}$ )

Claus Jacobsen holdt dog ud til 1859, men denne gang blev vanskelighederne med at finde en ny ikke mindre. En opfordring fra amtet til en gårdmand i Hynding med det ikke just fremmedklingende navn Hans Harısen om at overtage den ledige bestilling, afslog denne med følgende meget sigende begrundelse: „Nicht tauglich, da ich der dänischen Sprache nicht mächtig bin, indem ich dänisch zu schreiben nicht gelernt habe und mich schriftlich in derselben nicht verständigen kann! ${ }^{i i}$ Selv om vi ovenfor har set, at tyskundervisningen var blevet fremmet $i$ sognets skoler $i$ årene op til 1850, skal disse ord dog næppe opfattes som andet end et udtryk for, hvor den gode Hans Hansen havde sine sympatier. Han sluttede da også sit afslag med spagfærdigt at tilstå: „Wohl kann ich dänisch sprechen." -

Valget faldt derefter på Anthoni Lorenzen Thomsen fra Hynding, der imidlertid kun fik lov til at fungere $i$ halvandet

:) LA. Tdr. amtsarkiv. Journalsager G. 1851. 
år, idet han ved stændervalget i 1860 åbenbarede sit sande sindelag ved at stemme på hjemmetyskernes førende mand på den tid, storbonden Daniel Hinrichsen fra $\varnothing$. Terp. $\left.{ }^{* 6}\right)$ Det var Tonders nye amtmand, grev Brockenhuus-Schack, der greb ind over for sognefogeden efter en henvendelse fra kammerherre Heltzen i Åbenrå. ${ }^{27}$ ) Sognefogeden trøstede sig dog ved at erklære, at han i sin tid var blevet presset til at påtage sig hvervet. ${ }^{28}$ ) Myndighederne havde nemlig nok vidst, at han ingenlunde var den danske sag hengiven, men alligevel ansat ham, da en blakket var bedre end en ren tysksindet.

Man stod derefter påny overfor spørgsmålet om at finde en egnet loyal mand til sognefoged i Rabsted. Hvor meget det kneb, fremgår bedst af, at amtet så sig nødsaget til at opfordre $H$. P. Jørgensen i Korup, der var sognefoged for de løgumklosterske gårde i Rabsted sogn, til at overtage en tondersk gård. Det blev imidlertid ikke til noget, og valget faldt derefter på Jacob Jørgensen i Foverup, der, som vi siden skal høre, var den helt rigtige.

I halvdelen af Slogs herreds seks sogne indsattes der efter treårskrigen nye danske præster. I Burkal, Bylderup og Højst fik henholdsvis Joh. Kok, Holten Lützhöft og Sabinus Høxbro deres fremtidige virke. I Hostrup fortsatte derimod Chr. Hoeck i embedet, skønt han med årene kun slet forstod at dølge sine slesvigholstenske sympatier. I Rabsted og Tinglev forblev to mænd af den gamle skole, nemlig Meyer og Beyer, der vel rærmest har søgt at holde de gamle helstatssynspunkter i hævd. De tilhørte således en slægt, der ikke havde forstâet,

(26) S. årb. 1951, s. $161 \mathrm{ff}$.

27) S. årb. 1942, s. 219-220 (brev fra Vilh. Hagerup 1. 12. 1860). Dannevirke fra 1860 21/11. ser sig i stand til at nævne tre mænd. som фrigheden hædrer, der har stemt tysk, nemlig sognefogeden i Rabsted, sandemanden i Bylderup og kromanden i Bredevad.

28) I Itzehoer Nachrichten 1860 15/12. har Anthoni Thomsen fortalt om affæren. Dannevirke havde nægtet at optage hans indlæg (Dannevirke 1860 19/12). Se nærinere i S. mdskr. 1953, s. 45-47. 
at broderkrigen havde skabt et ulægeligt brud imellem mennesker af samme rod i en fælles hjemstavn, at nationalismens århundrede nu var indledt. I et indlæg i Dannevirke, hvor forståelsen for helstatsprincippet var ringe, stempledes Beyer sammen med flere andre præster som tysksindet. ${ }^{29}$ )

Den navnkyndigste af herredets præster blev Johs. Kok. Det er dog betegnende nok som forfatter og ikke som præst, at han har gjort sig kendt. Ikke uden fanatisme gik han ind for tidens nationalliberale opfattelse af det slesvigske spørgsmål. Ofte kan han i nutidens øjne virke noget naiv. Sit tyske slægtsnavn lod han således fra begyndelsen af 1860'erne stave på dansk, ligesom han i sin kirkebog gennemførte en „danisering" af sine sognebørns slægtsnavne. Kun et enkelt eksempel skal nævnes: Roth skrev han "Rød“" ${ }^{30}$ ) hvilket naturligvis måtte falde den pågældende familie for brystet. Hans omfattendeog i høj grad fortjenstfulde virksomhed som forfatter kan derfor i lighed med, hvad der samtidigt var tilfældet i mange sydslesvigske præstegårde, ses som udtryk for manglende kontakt med befolkningen: præstegerningen formåede ikke at båndlægge alle præstens kræfter. Uden at vi iøvrigt skal fordybe os nærmere i disse præsters virke, der så ofte tidligere er gjort til genstand for mere indgående behandling, kan det vist roligt fastslås, at den ellers så navnkundige pastor Kok har været den af de danske præster, hvis virke vandt mindst anerkendelse på selve egnen. Ved forjagelsen i 1864 stod en mand som pastor Lützhøft helt anderledes stærkt $i$ befolkningen.

Der kan nemlig ikke herske tvivl om, at befolkningen i Slogs herred i sin hovedmasse var dansksindet, hvad også alle beretninger fra tiden tyder på. Pastor Kok mente endog at kunne reducere de tysksindedes antal til en tyvendedel af sit sogns indbyggere ${ }^{31}$ ) hvilket vel nok har været alt for optimistisk,

29) Dannevirke 1860 4/9. De andre præster var: Carstens, Tønder, Göttge, Ubjerg, Holm, Aventoft, og Jessen, Abild.

30) S. årb. 1894, s. 122.

31) Slesvigske Provindzial-Efterretninger I (1860), s. 77. 
men ved pastor Lützhøfts fordrivelse fra Bylderup gav en afstemning forholdet 120 danske: 15 tysksindede. ${ }^{32}$ ) Amtmand grev Brockenhuus-Schack anså også dansk sindelag for aldeles overvejende, selv om han fandt befolkningen ligegyldig i politisk henseende..$^{33}$ )

De toneangivende større bønder - op under 1864 var det brødrene Mommsen på Store Tønde og Vrågård - var tysksindede, og de danske småkårsfolk gik derfor i reglen stille med, hvad de tænkte og følte. Den sociale deling indenfor landbostanden var meget udpræget i det gamle Slogs herred. Gang på gang dukker delingen efter hartkornstallet frem i aktstykker fra datiden. $\mathrm{Da}$ anlægget af en skolesti fra Skovhus til Lydersholm var på tale i 1850, fordi en indsidders børn havde store vanskeligheder med at komme i skole, erklærede bylaget kategorisk, at man ikke godvilligt agtede at udlægge en skolesti „for en Hyerling“; det havde været noget helt andet, dersom det havde drejet sig om ejeren af Skovhus! ${ }^{34}$ ) Da overklassen som nævnt gennemgående var tyskorienteret, kan det ikke undre, at man i tyske kredse mente at være i majoritet, når der regnedes efter kvalitet og ikke kvantitet! Et enkelt eksempel på en sådan tænkemåde er anført nedenfor.

Hvorom alting er, kan det med god grund fastslås, at den stærke hjemmetyskhed i Slogs herred ved genforeningen i 1920 i ikke ringe grad skyldes det fremmedherredømme, der satte ind efter 1864. Det lykkedes faktisk tyskheden at gøre folkelige erobringer blandt politisk indifferente, de „blakkede“, men det kan også noteres, at det ikke er lykkedes tyskheden at fastholde disse elementer i tiden, der fulgte efter 1920.

s2) S. mdsskr. 1950, s. 108.

3s) Danske Magazin 6. Rk. III, s 9. Fra tysk side har den konst. amtmand de Fontenay i Tønder bekræftet denne opfattelse. Han udtaler (1864 15/6), at stemningen i Slogs herred er mat (sflau*); herredet rørte sig ikke [til fordel for tyskheden] (Quellen $u$. Forschungen z. Gesch. Schl. H. II 113).

34) LA. Afl. Kiel C. VI 2. 699. 
Tyskernes overtagelse af administrationen i 1864 synes $i$ Slogs herred i det store og hele at være gået ret roligt for sig. Herredsfoged Cohen, der i tiden mellem krigene gennemførte de danske myndigheders foranstaltninger til punkt og prikke, fortsatte uanfægtet efter krigen som et lydigt redskab for de nye magthavere. For befolkningen har han stået som beviset for, at det virkeligt lod sig gøre at foretage en så radikal kursændring, og en del har åbenbart ladet sig smitte af eksemplet. De danske præster, der ret omgående blev fordrevet - kun fra Burkal meldes der om, at enkelte sogneboere tog del heri - har ikke mere kunnet nære den dårlige samvittighed.

Kun fra herredets to yderpoler, det tysksindede Rabsted og det danske Rørkær, meldes der om, at sindene er blevet sat $\mathrm{i}$ røre. ${ }^{35}$ )

Den 29. marts mødte en deputation fra Rabsted op hos den konstituerede amtmand i Tønder. Den krævede omgående indforelse af tysk skolesprog eller i det mindste ligeberettigelse af tysk og dansk. Læreren i Rabsted, en født alsinger, kunne begge sprog, men han var dansksindet, mens hans kollega i Foverup i 1864 gjaldt for at høre til i den modsatte lejr, og Havsted-læreren holdt sig politisk rolig; derimod var alene læreren i Korup ude af stand til at undervise i tysk, da han var fra enklaverne.

Endvidere krævede deputationen omgående fjernelse af sognefoged Jacob Jorgensen, der betegnedes som fanatisk dansk, ligesom den bragte bestemte forslag med hensyn til besættelsen af de mindre bestillinger i sognet (sandemand, taxator etc.).

Til slut krævedes genindførelsen af "de gamle navne“ på byerne - altså stednavne i tysk klædedragt -, og i stedet for rødt og hvidt ønskede man "die Landesfarben“, eventuelt andre farver! Rabsted-tyskerne har altså ligesom deres trosfæller ud

35) LA. Tdr. amtsarkiv. Sager ang. afskedigelser og udnævnelser af sognefogeder ca. $1848-68$. 
over det ganske Slesvigholsten i det begivenhedsrige år været i vildrede med deres hjemstavns kommende politiske status. Preusseren Bismarcks ord om hanekyllingerne, han selv var i stand til at dreje halsen om på, har åbenbart ikke været uden virkning.

For at fremme myndighedernes iver efter at gribe ind over for de danske, foranstaltedes en række optøjer. Det meldtes, at roen i sognet $i$ den sidste tid var blevet forstyrret ved skandaløse optog. I Petersens kro afholdt en snes mennesker endog en art afstemning for eller imod sognefogeden. 20 stemmer faldt til fordel for den tidligere foged Nicolaysen, mens 3 vovede at holde fast ved Jørgensen.

Denne lod sig dog ingenlunde slå ud af sin afsættelse. Da opsigelsesbrevet fra Tønder var affattet på tysk, nægtede han at anerkende modtagelsen med følgende begrundelse (1864 5/7): „Jeg skal gjerne indrømme, at jeg nogenlunde forstaaer 'Tydsk, hvori fornævnte Skrivelse er affattet, men i en for mig saa vigtig Sag som den nærværende, vil Ingen kunne fortænke mig i, at jeg, hvis jeg har Ret til det, fordrer Øvrighedens Udtalelse til mig i det Sprog, som jeg tilfulde forstaaer, mit danke Modersmaal. Efter alt hvad jeg har bragt i Erfaring ere de Lovbestemmelser, hvorefter Rets- og Forvaltningssproget i Slogs Herred udelukkende er dansk, ikke bleven ophævet. Jeg tillader mig derfor i al Erbødighed, idet jeg kun henholder mig til Lovgivningens Bestemmelser, at anmode det høie Amtshuus om at meddele mig Indholdet af nævnte Skrivelse af 2. d. M. i det danske Sprog." Mærkeligt nok føjede man sig i Tønder efter sognefogeden, og få dage senere modtog han sin afsked på dansk!

I Rørkær var sognefoged Peter Lund anstødsstenen. Han var efter tyskernes mening en mand, som de danske embedsmænd havde anset for det bedste redskab til deres propaganda. Folk som grev Brockenhuus-Schack og herredssfoged Kiær havde ved det sidste stændervalg udset ham til at repræsen- 
tere distriktet. En sådan mand kunne man derfor ikke beholde i embedet, tilmed da de danske knyttede forhåbninger til hans forbliven. „Patriotische Zwecke mit dänischen Werkzeugen zu erreichen ist unmöglich."

Imidlertid indsendte beboerne af de solvigske gårde en protest imod Peter Lunds afsættelse. Herredsfoged Reeder fastslog dog ved den lejlighed i overensstemmelse med de større grundejeres synsmåder, at det ikke kom an på stemmernes antal, men på deres vægt! Af de „store og intelligenteste kommuneinteressenter" havde ingen underskrevet, derimod nok daglejere, indvandret fra Jylland! Hermed har tyskheden i naticnalitetskampen anlagt et princip, der ganske stred imod den fremtidige udvikling i retning af demokrati, noget, der siden har været en hemsko i den tyske kulturkamp, mens forholdet indtil folkestyrets gennembrud i Danmark nærmest havde været lige omvendt.

Slogs herred var ved afståelsen i 1864 et godt dansk land. Det fortjener at fremhæves, at valgene til den nordtyske rigsdag i 1867 viste et klart dansk flertal overalt i herredet, alene med undtagelse af Rabsted. Men takket være den komplette mangel på ledende danske personligheder lykkedes det under fremmedårene tyskheden at vinde terræn, et af beviserne for, at en meget væsentlig del af det nuværende hjemmetyskeri skyldes mindelser fra kejserrigets gyldne dage. De jævne danske småkårsfolk har i Slogs herred mere end andetsteds i Nordslesvig følt sig trykket af de nationalt ugunstige forhold. Men deres danskhedstilkendegivelse i 1867 og 1920 vil ud i al fremtid bevidne vor nuværende statsgrænses berettigelse som det mest retfærdige skel mellem dansk og tysk, der har kunnet trækkes. Og for at en grænse kan ligge fast, må den søge sin berettigelse i historien!

Hans Vald. Gregersen. 
